\title{
Carbon stock changes in a peaty gley soil profile after afforestation with Sitka spruce (Picea sitchensis)
}

\author{
Argyro ZERVA, Maurizio MENCUCCINI* \\ School of GeoSciences (IERM), Edinburgh University, Darwin Building, Mayfield Rd, Edinburgh EH9 3JU, United Kingdom
}

(Received 13 April 2004; accepted 16 February 2005)

\begin{abstract}
We investigated the changes of carbon $\left(\mathrm{C}_{\mathrm{org}}\right)$ stocks in the litter $\left(\mathrm{O}_{\mathrm{L}}\right)$, organic $\left(\mathrm{O}_{\mathrm{H}}\right)$ and mineral $(\mathrm{A})$ layer after afforestation and at different stages after clearfelling of the first rotation, in a forest chronosequence of Sitka spruce (Picea sitchensis) on peaty gley soil, in Harwood Forest (N.E. England). The sites chosen were: unplanted natural grassland, 40-yr-old first rotation, 18 months-old clearfelled, and 12, 20 and a $30 \mathrm{yr}$-old second rotation. A further comparison was carried out in three 40 -yr-old stands between unplanted stripes of land (rides) and adjacent forest. Measurements of soil $\mathrm{C}_{\text {org }}$ were conducted with two methods, i.e., weight loss on ignition (L.O.I.) and dry combustion by C/N analysis. The results from two methods were linearly related. Afforestation changed both the total amounts and the distribution of the $\mathrm{C}_{\text {org }}$ stocks from the unplanted natural grassland. The total stocks of $\mathrm{C}_{\text {org }}$ decreased during first rotation and increased during second rotation to values similar to those found in the unplanted grassland. The vertical distribution of $\mathrm{C}_{\text {org }}$ also changed, with proportionally more carbon stored in the $\mathrm{O}_{\mathrm{L}}$ and inside the $\mathrm{A}$ layer and less in the organic layer after afforestation and two rotations.
\end{abstract}

soil carbon stocks / bulk density / C concentration / Sitka spruce / forest management / peaty gley soil

Résumé - Changement des stocks de carbone dans le profil des sols tourbeux à gley après boisement avec l'épicéa de Sitka (Picea sitchensis (Bong.) Carr). Les variations de stocks de carbone $\left(\mathrm{C}_{\mathrm{org}}\right)$ dans la litière $\left(\mathrm{O}_{\mathrm{L}}\right)$, dans l'horizon organique $\left(\mathrm{O}_{\mathrm{H}}\right)$ et l'horizon minéral $(\mathrm{A})$ ont été étudiées après boisement et à différents stades après coupe rase de la première rotation, dans une chronoséquence forestière de l'Epicéa de Sitka (Picea sitchensis) sur des sols tourbeux à gley en Forêt d'Hardwood (N.E. Angleterre). Les sites choisis étaient les suivants : prairie naturelle, première rotation âgée de 40 ans, coupe rase depuis 18 mois, et 12,20 et 30 ans de deuxième rotation. Une comparaison supplémentaire a été faite dans trois peuplements âgés de 40 ans entre des bandes de terre non plantées et dans une forêt adjacente. Les mesures de $\mathrm{C}_{\text {org }}$ ont été menées en utilisant deux méthodes : pertes de poids par ignition (L.O.I.) et combustion sèche par analyse du C/N. Les résultats des deux méthodes étaient linéairement liés. Le boisement change à la fois l'importance et la distribution des stocks de $\mathrm{C}_{\text {org }}$ des prairies naturelles. Les stocks totaux de $\mathrm{C}_{\text {org }}$ décroissent pendant la première rotation et s'accroissent pendant la seconde rotation vers des valeurs similaires à celles trouvées dans les prairies non plantées. La distribution verticale de $\mathrm{C}_{\text {org }}$ change aussi avec proportionnellement plus de carbone stocké dans la litière (OL) et dans l'horizon A et moins dans l'horizon organique après le boisement et deux rotations.

stocks de carbone dans le sol / densité volumique / concentration en C / épicéa de Sitka / aménagement forestier / sol tourbeux à gley

\section{INTRODUCTION}

Soils constitute a significant reservoir of carbon (C) in both organic and mineral forms and can play an important global role, by mitigating or contributing carbon to the atmosphere. Globally, soils contain more than two thirds of the total C stored in vegetation $[9,22]$ and almost twice the amount in the atmosphere [22], while forest soils (including peaty soils) contain approximately $69 \%$ of the total forest $\mathrm{C}$ pool [4]. The soil $\mathrm{C}$ in temperate forests is estimated to vary from 104 to $142 \mathrm{Pg}[22$, $30]$, while in Europe approximately $35 \%$ of the total $\mathrm{C}$ in the soils is held within high organic matter soils ( $\geq 8 \%$ organic matter) [24].

The amount of $\mathrm{C}$ stored in the soil is the balance between inputs of organic material from the biota, which depends on the type of vegetation and its productivity at a particular site, and losses, primarily through soil microbial respiration [18]. Forests continuously recycle $\mathrm{C}$ through photosynthesis and respiration; however, the net sequestration of $\mathrm{C}$ in vegetation and especially in soil can range over time periods from years to centuries, depending on the species, site conditions, disturbances regime and management practices [4].

Currently, forest plantations globally occupy an area of $187 \times 10^{6}$ ha; however, they account for less than $5 \%$ of the global forest cover [5]. Recent trends towards harvesting younger stands raise concerns about how such forest management will impact on soil processes and global carbon sequestration [15]. Forest plantations are often planted in areas that did not have forest cover before (at least in temperate regions), such as grasslands or abandoned agricultural land. At establishment, site

\footnotetext{
* Corresponding author: m.mencuccini@ed.ac.uk
} 
preparation may involve disturbing the soil, e.g. by the creation of drainage ditches or ploughing. These practices may accelerate organic matter decomposition by disturbing soil structure and breaking soil aggregates, leading to a loss of soil $\mathrm{C}[14,31]$.

Substantial losses of $\mathrm{C}$ from vegetation and soils can also be caused by harvesting [10]. Soil carbon storage is likely to initially decline after clear cutting, because $\mathrm{C}$ inputs from plant production are too low to counteract losses by soil respiration. Furthermore, intensive forest management may also lead to long-term decreases in soil organic matter content [9]. On the other hand, regenerating forests and plantations may represent important carbon sinks as a result of carbon storage in both plant biomass and soils [12]. Carbon accumulation rates during afforestation depend on tree species, soil type and the length of the rotation [29].

In Britain, about 315000 ha of shallow peatlands (mainly peaty gleys) have been planted with coniferous forests, mostly Sitka spruce (Picea sitchensis (Bong.) Carr) [3]. Afforestation on peaty soils may cause an increase in the rates of oxidation of the peat due to improved aeration by the drainage and the lowered water table under a maturing tree stand [16]. Growing trees can sequester carbon in the aboveground biomass as well as in the litter layer and soil; however, whether or not afforestation will give a net benefit of $\mathrm{C}$ sequestration depends on the rate of peat oxidation.

Two commonly used methods for measuring soil $\mathrm{C}$ are: (a) the weight by loss on ignition (L.O.I.) which measures organic $\mathrm{C}\left(\mathrm{C}_{\text {org }}\right)$ content by measuring mass loss following high temperature combustion at approximately $500^{\circ} \mathrm{C}$ and (b) dry combustion by $\mathrm{C} / \mathrm{N}$ analysers where samples are oxidised at high temperature (approximately $1000{ }^{\circ} \mathrm{C}$ ) and then the $\mathrm{CO}_{2}$ gas evolved is measured by infrared gas absorption analysis (IRGA) or gas chromatography (GC). The use of $\mathrm{C} / \mathrm{N}$ analysers is expensive and the high temperature oxidation also liberates $\mathrm{C}$ from carbonate minerals, thus a separate analysis for the separation of carbonate- $\mathrm{C}\left(\mathrm{C}_{\min }\right)$ is sometimes required. The ignition temperature used for L.O.I. is below that at which $\mathrm{C}_{\min }$ decomposes [11] and the use of L.O.I. has been suggested, as long as it is checked against a dry-combustion method [25].

Soil carbon storage is an important factor for ecosystem stability in the long-term, but small changes in a large pool are difficult to detect, although even small changes in the soil carbon pool can result in relatively large changes in fluxes of $\mathrm{CO}_{2}$ to the atmosphere. The vital role of soils as a sink or source for $\mathrm{C}$ at the global scale in offsetting atmospheric $\mathrm{CO}_{2}$ concentrations [13] makes it important to accurately evaluate the effects of forest management on soil C storage.

The objective of the study was to examine the effects of afforestation on peaty gley soils with Sitka spruce and forest management on soil C stocks within the soil profile. The overall aim was to gain some insight into the long-term effects of afforestation, forest harvesting and reforestation on soil $\mathrm{C}$ stocks.

\section{MATERIALS AND METHODS}

\subsection{Site description}

Measurements were made in various stands within Harwood forest $\left(55^{\circ} 10^{\prime} \mathrm{N}, 2^{\circ} 3^{\prime} \mathrm{W}\right)$, in Northamberland, England. Harwood forest mostly consists of even aged stands of pure Sitka spruce (Picea sitch- ensis (Bong.) Carr.). The area rises from $200 \mathrm{~m}$ in the South-East to $400 \mathrm{~m}$ in the North-West. Average annual precipitation is $950 \mathrm{~mm}$, mean annual temperature is $7.6^{\circ} \mathrm{C}$. The dominant soil type is peaty gley, i.e., a seasonally waterlogged soil with a superficial organic-rich layer [19].

The establishment of the forest started in the 1930s with the planting of ericaceous moorland. The trees were planted on top of small ridges following ploughing, i.e., a process that resulted in a peculiar structure of the soil profile. In the furrows the organic horizon is often absent. On the ridges there is often an inversion of the usual horizon arrangement $\left(\mathrm{O}_{\mathrm{L}}, \mathrm{O}_{\mathrm{H}}, \mathrm{A}\right)$, with the $\mathrm{A}$ horizon above the $\mathrm{O}_{\mathrm{H}}$, and the $\mathrm{O}_{\mathrm{L}}$ horizon in deeper layers.

The forest is managed with rotations of about 40 years. At this age a whole stand is clearfelled and the planting of trees takes place after two or three years. Tree harvesting is conducted by mechanical harvesters with a mechanically operated harvesting head that fells a tree, de-limbs it, and transfers the logs to a special extended rear frame and carries them out of the forest. The slash is left on site to create the bed over which the harvester moves. Subsequently, the brash is accumulated into large heaps to make room for planting. Based on visual observations, these processes created a surface layer of mixed organic material, logging slash, twigs and roots.

\subsection{Soil sampling}

The detailed methodology for soil $\mathrm{C}$ sampling and analysis is described in [31] and will only be outlined here. Soil sampling took place during the summers of 2000 and 2001. The research was undertaken in stands of different ages to represent the continuum of stand development since initial afforestation, an area where a mature stand had been clearfelled, and areas under natural moorland that were representative of the land cover prior to forest establishment. All stands were on peaty gley soils. The following stands were sampled: three first-rotation 40-yr-old, three 30-yr-old, three 20-yr-old, and four 12 -yr-old stands, all of which during second rotation. Two unplanted (grassland) areas were also used, together with a single clearfelled area (CF), for which no comparable replicate was available. The two unplanted grassland sites were chosen inside the forest in areas left unplanted for conservation reasons, but still on the same soil type.

For each stand, we sampled between 1 and 5 plots, with between 8 and 9 soil cores taken from each plot. In the summer 2000, five plots were sampled from each stand, to determine the within- as well as the among-plot variability. In 2001, given that most of the variability was within, not among, plots, number of plots/stand was reduced to one. Soil samples were taken using a manually driven soil corer with a slide hammer attachment (Giddings Machine Company, Inc., USA) $(5.5 \mathrm{~cm}$ diameter) or a soil auger $(2.5 \mathrm{~cm}$ diameter $)$, to a depth of about $45 \mathrm{~cm}$. Tests were also carried out to compare the estimates obtained with the auger with those obtained with the corer. Twenty-eight individual cores were taken adjacent to one another with both corers in several different plots. The cores were separated into three layers (see below) and a $t$-test conducted to test whether significant differences existed in the estimation of soil $\mathrm{C}$ stocks by the two instruments. The values given by the two methods were not significantly different $(P>0.05)$ and the data were pooled.

An additional study was conducted in three 40-yr-old stands to compare soil $\mathrm{C}$ stocks inside the forest with soil $\mathrm{C}$ stocks in the unplanted rides in between forest stands. Rides are unplanted stripes of land ( 8 to $10 \mathrm{~m}$ wide) that separate blocks of forest $200 \mathrm{~m}$ wide. In a ride, litterfall is largely reduced, but depth of the water table may be as low as inside a block of forest, as two ditches border the ride on both sides. In three separate areas, we selected three paired plots (one in a ride, and one alongside in the forest) located as close to each other as possible and nine samples were taken for each plot.

All samples were transferred to the lab, where the depth of the total core was measured and then separated into three layers: the litter layer $\left(\mathrm{O}_{\mathrm{L}}\right)$, organic layer $\left(\mathrm{O}_{\mathrm{H}}\right)$ and mineral layer $(\mathrm{A})$. In the case of forest 
stands and the clearfelled site, the $\mathrm{O}_{\mathrm{F}}$ layer was included with the $\mathrm{O}_{\mathrm{H}}$ layer. In the unplanted grassland the $\mathrm{O}_{\mathrm{L}}$ layer was considered as the layer consisting of dead plant material and the layer of partly decomposed material (i.e., mostly $\mathrm{O}_{\mathrm{F}}$ ).

The samples were kept in polythene bags in a freezer $\left(-4^{\circ} \mathrm{C}\right)$ till further analyses. The samples were then oven-dried at $105^{\circ} \mathrm{C}$ for $24 \mathrm{~h}$ to constant weight [1]. Stone content was negligible. Any stones present and coarse fragments were removed by hand and the soil was ground to pass a $0.5 \mathrm{~mm}$ mesh [25].

\subsection{Determination of $\mathrm{C}$ concentration}

Thirty per cent of all samples from all layers were analysed both in a $\mathrm{C} / \mathrm{N}$ analyser (Carlo-Erba, NA 2500) and by loss on ignition (L.O.I.). Finely ground sub-samples of about $4 \mathrm{mg}$ for the litter and the organic layer and $10 \mathrm{mg}$ for the mineral layer were combusted in the $\mathrm{C} / \mathrm{N}$ analyser, and their $\mathrm{C}$ concentration $\left(\mathrm{g} \mathrm{kg}^{-1}\right)$ was determined. Total $\mathrm{C}$ was assumed to equal organic $\mathrm{C}$, as the samples did not come from a calcareous soil. Other sub-samples of approximately $1 \mathrm{~g}$ [1] were weighed and then ignited in a furnace at $500^{\circ} \mathrm{C}$, for $5 \mathrm{~h}$ (L.O.I.). After burning the samples were weighed again and the percentage mass loss (L\%) was calculated, to determine the relationship between $\mathrm{C}$ and $\mathrm{L} \%$.

\subsection{Soil bulk density}

Soil bulk density was calculated for the samples from the 2001 study only, because no layer depths had been measured during the 2000 study. Bulk density was calculated with the following formula:

$$
P_{\mathrm{b}}=M / V
$$

where $P_{\mathrm{b}}$ is the bulk density $\left(\mathrm{g} \mathrm{cm}^{-3}\right), M$ is the dry mass of a given soil sample $(\mathrm{g})$ and $V$ its fresh volume $\left(\mathrm{cm}^{3}\right)$. Only few small stones were found in the cores.

\subsection{Statistical analysis}

The slopes of the regression equations for the relationship between the $\mathrm{C}\left(\mathrm{g} \mathrm{kg}^{-1}\right)$ obtained from $\mathrm{C} / \mathrm{N}$ analyser and the $\%$ mass loss from L.O.I. methods for each of three layers $\left(\mathrm{O}_{\mathrm{L}}, \mathrm{O}_{\mathrm{H}}, \mathrm{A}\right)$ was tested by ANCOVA (Analysis of Covariance) in SPSS [26].

The data from both study years were first analysed separately to determine whether significantly different patterns emerged as a result of the different methodologies employed. Because the patterns were similar, the data were combined and the mean was used as the soil C stock for each site. Differences among age classes were tested using one-way ANOVA (Analysis of Variance), using plot averages as the unit for analysis. Because of the lack of site replication in the case of the $\mathrm{CF}$, the site was not included in the ANOVA analysis.

A Mann-Whitney test was employed for the comparison between the 40-yr stands and the ride plots, as the ride values did not follow a normal distribution. One-way ANOVA was performed using SAS [20] and equations were fitted using Sigma Plot. All the probabilities were tested at the 5\% significance level.

\section{RESULTS}

\subsection{Equation for predicting soil $\mathrm{C}$ using the L.O.I. method}

When the mass loss (\%) by L.O.I was plotted against the $\mathrm{C}$ concentration (\%) obtained by the $\mathrm{C} / \mathrm{N}$ analyser, a significant linear relationship was obtained $\left(R^{2}=0.98\right.$, Fig. 1). ANCOVA revealed significant differences in the slopes of the regression equations among the 3 layers $(P<0.05)$. Thus, separate regression equations were fitted for each layer [31]:

$$
\begin{aligned}
& \mathrm{C}\left(\mathrm{g} \mathrm{kg}^{-1}\right)=0.513 \mathrm{~L}(\%)-0.092, R^{2}=0.99 \text { for } \mathrm{O}_{\mathrm{L}} \\
& \mathrm{C}\left(\mathrm{g} \mathrm{kg}^{-1}\right)=0.542 \mathrm{~L}(\%)+0.184, R^{2}=0.99 \text { for } \mathrm{O}_{\mathrm{H}} \\
& \mathrm{C}\left(\mathrm{g} \mathrm{kg}^{-1}\right)=0.533 \mathrm{~L}(\%)-0.700, R^{2}=0.99 \text { for } \mathrm{A} .
\end{aligned}
$$

\subsection{Soil $\mathrm{C}$ stocks in the litter, organic and mineral layers along the chronosequence}

Soil $\mathrm{C}_{\text {org }}$ stocks in litter, organic and mineral layer down to $45 \mathrm{~cm}$ depth at each site are presented in Figure 2. The change of total soil $\mathrm{C}$ stocks along the chronosequence can be found in Zerva et al. [31]. $\mathrm{C}_{\text {org }}$ in the $\mathrm{O}_{\mathrm{L}}$ layer in the UN site (also inclusive of $\mathrm{O}_{\mathrm{F}}$ ) was $18.2 \pm 4.5 \mathrm{t} \mathrm{C} \mathrm{ha}^{-1}$, i.e., significantly lower than $29.5 \pm 6.3 \mathrm{t} \mathrm{C} \mathrm{ha}^{-1}$ in the $\mathrm{O}_{\mathrm{L}}$ in the $40-\mathrm{yr}$ stands in first rotation $(P<0.05)$. The $\mathrm{O}_{\mathrm{L}}$ in the $\mathrm{CF}$ site contained $7.4 \pm 1.8 \mathrm{t}$ $\mathrm{C} \mathrm{ha}^{-1}$, i.e., considerably less than the $40-\mathrm{yr}$ stand, although this could not be tested statistically because of lack of inter-stand replication (the standard error given above refers to intra-stand variability). In second-rotation stands, $\mathrm{C}_{\text {org }}$ in the $\mathrm{O}_{\mathrm{L}}$ significantly increased from $16.4 \pm 0.8 \mathrm{t} \mathrm{C} \mathrm{ha}^{-1}$ in the 12 -yr stands to $20.4 \pm 1.8 \mathrm{t} \mathrm{C} \mathrm{ha}^{-1}$ in the 20 -yr stands and $27.7 \pm 1.5 \mathrm{t} \mathrm{C} \mathrm{ha}^{-1}$ in the $30-y r$ stands $(P<0.05)$. The changes in $\mathrm{C}_{\text {org }}$ in the $\mathrm{O}_{\mathrm{L}}$ were accompanied by changes in the thickness of the $\mathrm{O}_{\mathrm{L}}$ as well (Tab. I). The depth of the litter layer in the UN site was similar to the 40-yr stands. The $\mathrm{O}_{\mathrm{L}}$ layer in the single CF site was much thinner than the 40-yr, while during the second rotation $\mathrm{O}_{\mathrm{L}}$ thickness significantly increased with age from the 12 -yr to the 30 -yr stands. The thickness data refer to the 2001 sampling only.

$\mathrm{C}_{\text {org }}$ in the $\mathrm{O}_{\mathrm{H}}$ layer in the UN site was $243.2 \pm 60.3 \mathrm{t} \mathrm{C} \mathrm{ha}^{-1}$, i.e., significantly higher than the $65.8 \pm 9.3 \mathrm{t} \mathrm{C} \mathrm{ha}^{-1}$ in the $40-\mathrm{yr}$ stands at the end of the first rotation $(P<0.001)$. The single $\mathrm{CF}$ site had considerably lower $\mathrm{C}_{\text {org }}$ than the 40 -yr stands, although again this could not be tested. Soil $\mathrm{C}$ started increasing again as the stands grew in second rotation, from $108.6 \pm 34.3 \mathrm{t} \mathrm{C} \mathrm{ha}^{-1}$ in the 12 -yr stands to $115.1 \pm 6.1 \mathrm{t} \mathrm{C} \mathrm{ha}^{-1}$ in the 20 -yr stands (although $P>0.05$ ), but the increase became significant in the 30 -yr stands, with values of $173.3 \pm 26.3 \mathrm{t} \mathrm{C} \mathrm{ha}^{-1}(P<0.05)$. The thickness of the $\mathrm{O}_{\mathrm{H}}$ was reduced after the planting of trees (compare UN with the 40-yr stands), despite $\mathrm{O}_{\mathrm{F}}$ being bulked with $\mathrm{O}_{\mathrm{L}}$ for $\mathrm{UN}$ and with $\mathrm{O}_{\mathrm{H}}$ for 40-yr. The 12-yr and 20-yr stands were not significantly different for the thickness of their $\mathrm{O}_{\mathrm{H}}$, although the 30-yr stands had significantly deeper $\mathrm{O}_{\mathrm{H}}$ than the $12-y r$ stands.

The UN site contained $20.3 \pm 1.1 \mathrm{t} \mathrm{C} \mathrm{ha}^{-1}$ in the A layer, while significantly higher amounts were found in the same layer of the $40-\mathrm{yr}$ stands $\left(44.8 \pm 8.1 \mathrm{t} \mathrm{C} \mathrm{ha}^{-1}, P<0.0001\right)$. The A layer in the single CF site contained $64.4 \pm 15 \mathrm{t} \mathrm{C}$ ha $^{-1}$. In the $12-\mathrm{yr}$ in second rotation, soil $\mathrm{C}_{\text {org }}$ in the A layer was $22 \pm$ $15.5 \mathrm{t} \mathrm{C} \mathrm{ha}^{-1}$, in the 20 -yr stands in $45.3 \pm 16.9 \mathrm{t} \mathrm{C} \mathrm{ha}^{-1}$ and $48.4 \pm 11.9 \mathrm{t} \mathrm{C} \mathrm{ha}^{-1}$ in the 30 -yr stands, i.e., the values showed an increasing trend, although the differences were not significant $(P>0.05)$.

The average total soil $\mathrm{C}_{\text {org }}$ stocks in the rides next to $40-\mathrm{yr}$ stands were $129.7 \pm 14 \mathrm{t} \mathrm{C} \mathrm{ha}^{-1}$, while the average for the 


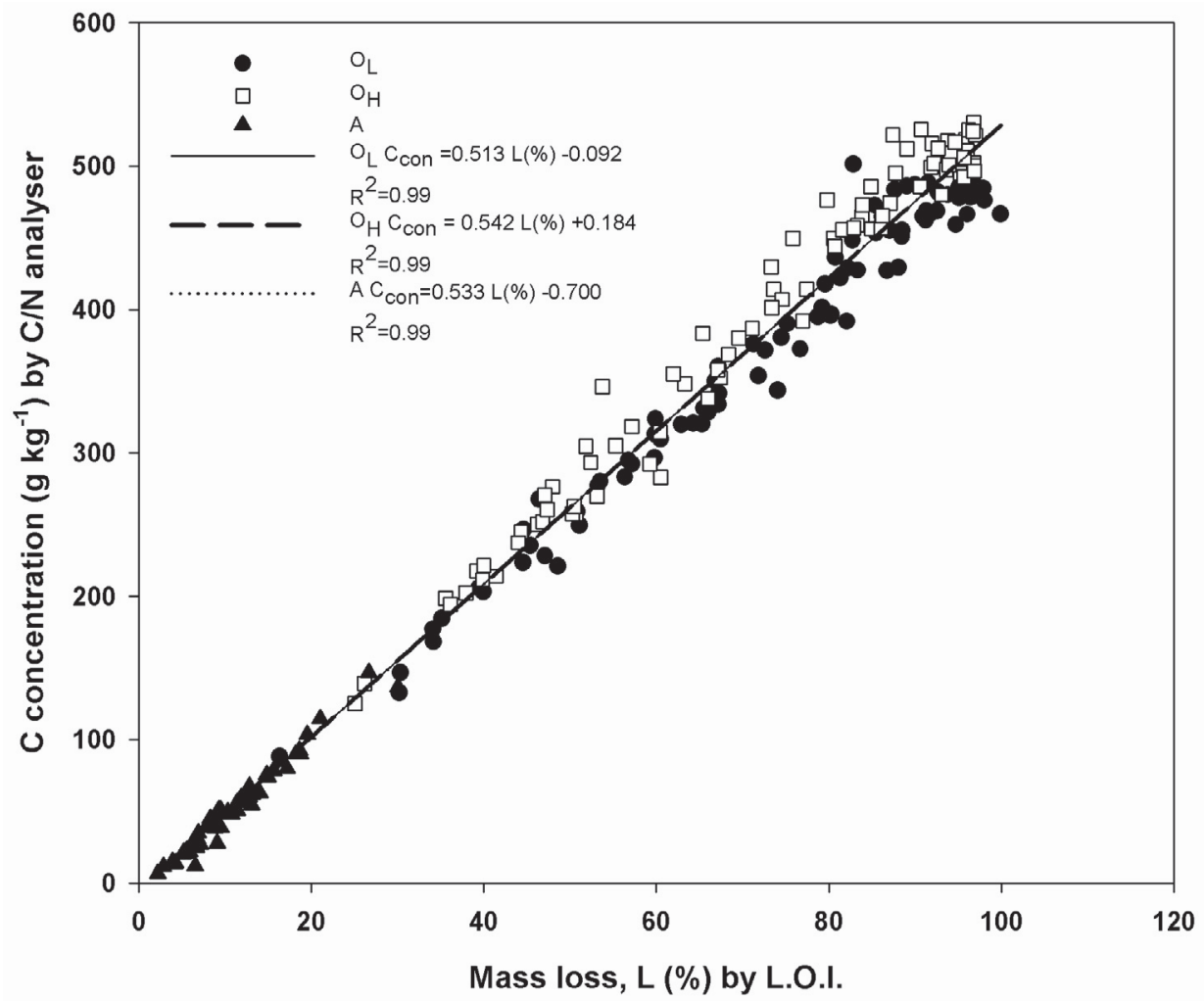

Figure 1. Linear regressions between mass loss L (\%) from L.O.I and $\mathrm{C}\left(\mathrm{g} \mathrm{kg}^{-1}\right)$ by $\mathrm{C} / \mathrm{N}$ analyser for 230 samples from $\mathrm{O}_{\mathrm{L}}$, $\mathrm{O}_{\mathrm{H}}$ and $\mathrm{A}$ layers and from different sites within Harwood forest.

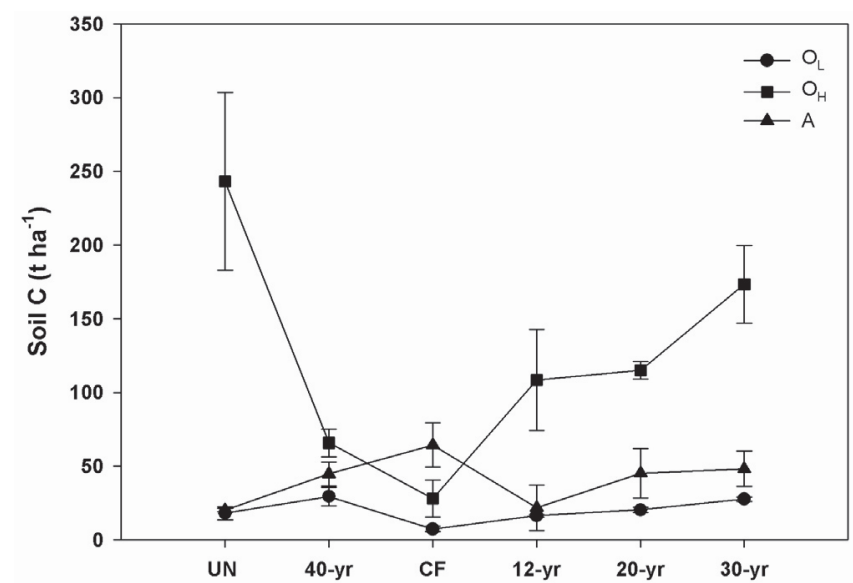

Figure 2. Soil C stocks $\left(\mathrm{t} \mathrm{ha}^{-1}\right)$ along the Sitka spruce chronosequence in $\mathrm{O}_{\mathrm{L}}, \mathrm{O}_{\mathrm{H}}$ and $\mathrm{A}$ layers. The vertical bars indicate the standard error of the mean across stands, except for $\mathrm{CF}$ where they indicate the standard error of the mean across plots.

40-yr forest plots was $127.0 \pm 17 \mathrm{t} \mathrm{C} \mathrm{ha}^{-1}$. Figure 3 shows the three pairs of study plots in rides and adjacent 40-yr stands. Although no significant difference $(P>0.05)$ was found for total $\mathrm{C}_{\text {org }}$ between rides and 40 -yr stands, there were different patterns in the vertical distribution of $\mathrm{C}$. The $\mathrm{C}$ in the litter layer of the 40-yr stand was significantly higher than the $\mathrm{C}$ contained in the litter layer of the ride $\left(19.6 \pm 3.6\right.$ and $6.7 \pm 1.1 \mathrm{t} \mathrm{C} \mathrm{ha}^{-1}$ respectively, $P<0.001$ ), while soil C stocks in the organic layer of the 40-yr stands were lower but not significantly different $\left(73.4 \pm 5.8\right.$ vs. $92.1 \pm 10.8 \mathrm{t} \mathrm{Cha}^{-1}$, in the 40 -yr stands and rides respectively, $P>0.05)$. No significant differences were observed for the mineral layer $\left(38 \pm 3.3\right.$ and $31.8 \pm 6.0 \mathrm{t} \mathrm{Cha}^{-1}$, respectively, $P>0.05$ ).

Bulk densities and $\mathrm{C}$ concentration for each soil layer are shown in Table I for the 2001 samples. Bulk density in the $\mathrm{O}_{\mathrm{L}}$ had varied between 0.1 and $0.2 \mathrm{~g} \mathrm{~cm}^{-3}$ at all sites, whereas the bulk density in the $\mathrm{O}_{\mathrm{H}}$ ranged between 0.34 and $0.86 \mathrm{~g} \mathrm{~cm}^{-3}$. Afforestation increased bulk density in the $\mathrm{O}_{\mathrm{H}}$ from $\mathrm{UN}$ to 40 -yr stands. For the stands growing in second rotation, bulk density in the $\mathrm{O}_{\mathrm{H}}$ decreased from the 12 -yr stand to the $30-\mathrm{yr}$ stand $(P<0.05)$. The bulk density in the mineral layer was very similar at all sites, with values ranging between 1.30 and $1.52 \mathrm{~g} \mathrm{~cm}^{-3}$.

$\mathrm{C}$ concentration in the $\mathrm{O}_{\mathrm{L}}$ did not significantly vary across the chronosequence and ranged between 339 and $453 \mathrm{~g} \mathrm{~kg}^{-1}$, increasing slightly in the second-rotation stands. UN had a high C concentration in the $\mathrm{O}_{\mathrm{H}}$, while afforestation resulted in a significantly lower $\mathrm{C}$ concentration in the first-rotation 40-yr stands $(P<0.001)$. C concentration increased significantly with stand age in the second rotation $(P<0.001)$. The $\mathrm{C}$ concentration in the mineral layer ranged from 18 to $29 \mathrm{~g} \mathrm{~kg}^{-1}$ and there were no significant differences between sites $(P>0.05)$. 
Table I. Bulk density $\left(\mathrm{g} \mathrm{cm}^{-3}\right)$, thickness $(\mathrm{cm})$ and $\mathrm{C}_{\mathrm{org}}$ concentration $\left(\mathrm{g} \mathrm{kg}^{-1}\right)$ for each layer of the chronosequence. Numbers in brackets indicate the standard error of the mean (across stands), except for CF, where it indicates the standard error of the mean (across plots); n. d.: not determined. Different letters for each site indicate significant differences (at least $P<0.05$ ): capital letters refer to $\mathrm{O}_{\mathrm{L}}$, smaller letters to $\mathrm{O}_{\mathrm{H}}$. None of the differences among mineral layers were significant $(P>0.05)$.

\begin{tabular}{|c|c|c|c|c|}
\hline Site & Layer & $\begin{array}{l}\text { Bulk density } \\
\qquad\left(\mathrm{g} \mathrm{cm}^{-3}\right)\end{array}$ & $\begin{array}{l}\text { Thickness } \\
(\mathrm{cm})\end{array}$ & $\begin{array}{c}\text { C concentration } \\
\left(\mathrm{g} \mathrm{k}^{-1}\right)\end{array}$ \\
\hline \multirow[t]{3}{*}{$\overline{\mathrm{UN}}$} & $\mathrm{O}_{\mathrm{L}}$ & $0.11(0.01)^{\mathrm{A}}$ & $3.8(0.9)^{\mathrm{A}}$ & $453(12)^{\mathrm{ns}}$ \\
\hline & $\mathrm{O}_{\mathrm{H}}$ & $0.55(0.1)^{\mathrm{a}}$ & $20.3(1.3)^{\mathrm{A}}$ & $399(34)^{\mathrm{A}}$ \\
\hline & A & $1.42(0.04)^{\mathrm{ns}}$ & n. d. & $16(5)^{\mathrm{A}}$ \\
\hline \multirow[t]{3}{*}{$40-\mathrm{yr}$} & $\mathrm{O}_{\mathrm{L}}$ & $0.15(0.02)^{\mathrm{A}}$ & $4.6(0.5)^{\mathrm{A}}$ & $339(32)^{\mathrm{ns}}$ \\
\hline & $\mathrm{O}_{\mathrm{H}}$ & $0.86(0.2)^{\mathrm{b}}$ & $12.8(0.7)^{\mathrm{C}}$ & $155(29)^{\mathrm{B}}$ \\
\hline & A & $1.52(0.03)^{\mathrm{ns}}$ & n. d. & $17(4)^{\mathrm{A}}$ \\
\hline \multirow[t]{3}{*}{ Rides } & $\mathrm{O}_{\mathrm{L}}$ & $0.18(0.03)$ & $1.8(0.3)$ & $311(76)$ \\
\hline & $\mathrm{O}_{\mathrm{H}}$ & $0.75(0.05)$ & $16.1(0.8)$ & $98(17)$ \\
\hline & A & $1.48(0.04)$ & n. d. & $18(4.4)$ \\
\hline \multirow[t]{3}{*}{$\mathrm{CF}$} & $\mathrm{O}_{\mathrm{L}}$ & $0.14(0.03)$ & $2.7(0.4)$ & $337(08)$ \\
\hline & $\mathrm{O}_{\mathrm{H}}$ & $0.49(0.04)$ & $6.3(1.4)$ & $138(21)$ \\
\hline & $\mathrm{A}$ & $1.35(0.08)$ & n. d. & $25(7)$ \\
\hline \multirow[t]{3}{*}{$12-\mathrm{yr}$} & $\mathrm{O}_{\mathrm{L}}$ & $0.16(0.01)^{\mathrm{B}}$ & $3.6(0.2)^{\mathrm{A}}$ & $339(38)^{\mathrm{ns}}$ \\
\hline & $\mathrm{O}_{\mathrm{H}}$ & $0.62(0.06)^{\mathrm{a}}$ & $16.9(1.8)^{\mathrm{B}}$ & $152(51)^{\mathrm{B}}$ \\
\hline & A & $1.39(0.05)^{\mathrm{ns}}$ & n. d. & $18(0.4)^{\mathrm{A}}$ \\
\hline \multirow[t]{3}{*}{$20-\mathrm{yr}$} & $\mathrm{O}_{\mathrm{L}}$ & $0.14(0.02)^{\mathrm{A}}$ & $4.7(0.6)^{\mathrm{A}}$ & $368(14)^{\mathrm{ns}}$ \\
\hline & $\mathrm{O}_{\mathrm{H}}$ & $0.40(0.04)^{\mathrm{c}}$ & $16.4(1.8)^{\mathrm{BC}}$ & $306(19)^{\mathrm{A}}$ \\
\hline & A & $1.36(0.05)^{\mathrm{ns}}$ & n. d. & $17(0.2)^{\mathrm{A}}$ \\
\hline \multirow[t]{3}{*}{$30-y r$} & $\mathrm{O}_{\mathrm{L}}$ & $0.11(0.01)^{\mathrm{A}}$ & $7.0(0.3)^{\mathrm{B}}$ & $402(35)^{\mathrm{ns}}$ \\
\hline & $\mathrm{O}_{\mathrm{H}}$ & $0.34(0.03)^{\mathrm{c}}$ & $20.9(1.4)^{\mathrm{A}}$ & $413(13)^{\mathrm{A}}$ \\
\hline & A & $1.30(0.04)^{\mathrm{ns}}$ & n. d. & $29(2)^{\mathrm{B}}$ \\
\hline
\end{tabular}

\section{DISCUSSION}

\subsection{Equation for predicting soil $\mathrm{C}$ using the L.O.I. method}

The strong linear relationships between the mass loss obtained by L.O.I. and the $\mathrm{C}(\%)$ by $\mathrm{C} / \mathrm{N}$ analyser for the three layers, $\mathrm{O}_{\mathrm{L}}, \mathrm{O}_{\mathrm{H}}$ and $\mathrm{A}$, indicates that L.O.I can be used as a precise method for estimating organic $\mathrm{C}$ from peaty gley soils, with the significant advantage of the low cost of the method. We found significantly different slopes for each layer, probably because of the different amounts of organic matter present in each layer, with the litter and organic layers containing more $\mathrm{C}$ per unit of mass loss than the mineral layer. Additionally, clay content and clay mineralogy have also been reported as significant factors in affecting these relationships. Konen et al. [17] developed equations for predicting organic $\mathrm{C}$ content (as deter- mined by $\mathrm{C} / \mathrm{N}$ analyser) from L.O.I for 255 non-calcareous samples from selected major land resource areas in the North Central USA. They found significant differences in the slopes of equations among each major land resource area. The strong predictive equations found here indicate that L.O.I can be a precise method that can be used successfully to predict accurately $\mathrm{C}\left(\mathrm{g} \mathrm{kg}^{-1}\right)$ in peaty gley soils in the Harwood forest area. L.O.I. may not be a true measure of organic matter, because at the temperature of ashing some bound water is lost from the clay minerals. This error is more serious in soils low in organic matter [1].

\subsection{Soil C stocks in the litter, organic and mineral layers}

Afforestation on previous grasslands on peaty gley soil caused changes in the $\mathrm{C}$ content in the $\mathrm{O}_{\mathrm{L}}, \mathrm{O}_{\mathrm{H}}$ and $\mathrm{A}$. Soil $\mathrm{C}_{\mathrm{org}}$ in the $\mathrm{O}_{\mathrm{L}}$ layer of $\mathrm{UN}$ was not significantly different from the 


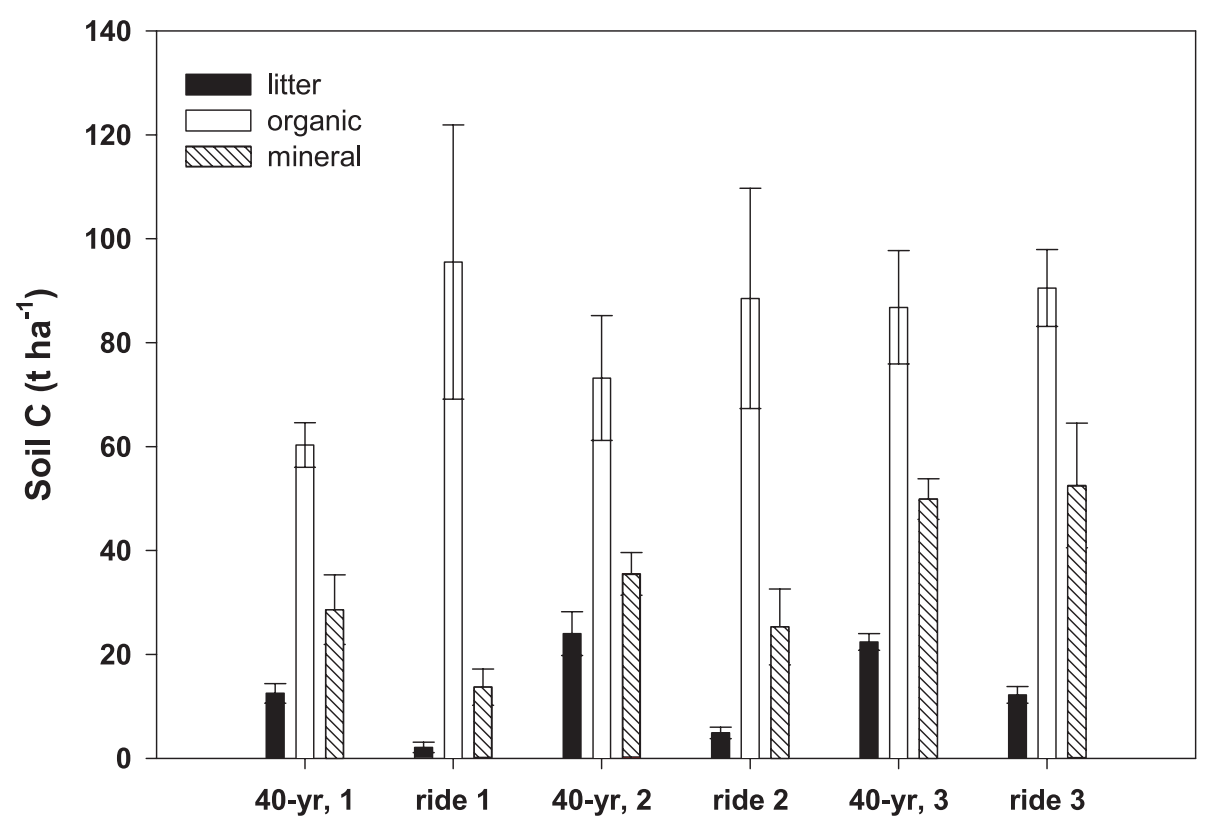

Figure 3. Soil $\mathrm{C}\left(\mathrm{t} \mathrm{ha}^{-1}\right)$ in litter, organic and mineral layers of three paired plots in 40 -yr stands and rides. The vertical bars represent the standard error of the mean.

40-yr stands, but the $\mathrm{C}$ stock in the $\mathrm{O}_{\mathrm{H}}$ layer was considerably higher in UN. This decrease could be due to the accelerated decomposition caused by the site preparation for drainage and for the planting of trees [3].

When soil $\mathrm{C}_{\text {org }}$ in the 40-yr stands was compared with the $\mathrm{C}$ stocks in adjacent unplanted rides, no significant difference was found, though one may have expected that the ride would resemble the unplanted grassland, since no site preparation or tree planting took place there (although each 8-m ride is bordered with one ditch on either side). The $\mathrm{O}_{\mathrm{L}}$ layer had significantly less $\mathrm{C}$ content in the rides. The extra $\mathrm{C}_{\text {org }}$ in the $\mathrm{O}_{\mathrm{L}}$ in the forest is a characteristic feature of this system. The decrease in $\mathrm{C}_{\text {org }}$ in the $\mathrm{O}_{\mathrm{H}}$ layer in the forest was not significant at the $5 \%$ significance level, although the trend was in the same direction as for the comparison between the UN sites and the 40-yr stands.

The considerably lower $\mathrm{C}_{\text {org }}$ content in the $\mathrm{O}_{\mathrm{L}}$ layer of the single CF compared to the 40-yr stands could be attributed to the cessation of litter input from harvested trees. The $\mathrm{O}_{\mathrm{H}}$ layer had also considerably lower $\mathrm{C}$ than the $40-\mathrm{yr}$ stands, probably as a result of increased losses through organic matter decomposition, but the A layer had considerably higher amount of $\mathrm{C}$. That could be attributed to the re-distribution of organic material after harvesting operation and the incorporation of slash in the soil. Johnson et al. [14] investigated the effects of clearfelling on soil carbon dynamics in a northern hardwood forest. A decrease of $20 \mathrm{tC} \mathrm{ha}^{-1}$, eight years after logging, was estimated, as well as a redistribution of carbon within the mineral soil, with an increase in $\mathrm{C}$ in the $\mathrm{A}$ and $\mathrm{E}$ horizons. Gholz et al. [7] found that the A horizon of a 2 yr-old stand of slash pine contained approximately twice as much soil $\mathrm{C}$ as the other stands of the chronosequence (up to the age of 34). This was attributed to bedded slash. The effect of slash was short lived, so by the age of 5 years, the soil $\mathrm{C}$ decreased to $50 \%$ of pre-harvest levels. In the CF slash was left behind, however the extent to which slash contributed $\mathrm{C}$ to the soil and prevented a greater loss of $\mathrm{C}$ from the site is not known.

In second-rotation stands, the amount of $\mathrm{C}_{\text {org }}$ in the $\mathrm{O}_{\mathrm{L}}$, as well as the thickness of $\mathrm{O}_{\mathrm{L}}$ and $\mathrm{O}_{\mathrm{H}}$ layers, increased as the amount of litterfall increased [31]. A linear accumulation of organic matter with stand age in the forest floor $\left(\mathrm{O}_{\mathrm{L}}\right.$ and $\mathrm{O}_{\mathrm{F}+\mathrm{H}}$ layers) was found in slash pine plantations in Florida [7].

In the 30-yr stands, the amount of $\mathrm{C}_{\text {org }}$ in the $\mathrm{O}_{\mathrm{L}}$ was significantly higher than in the grassland and the amount of $\mathrm{C}_{\mathrm{org}}$ in the $\mathrm{O}_{\mathrm{H}}$ layer was not significantly different than the one in UN.

Changes in the soil $\mathrm{C}_{\text {org }}$ stocks across the chronosequence were accompanied by changes in the concentration of $\mathrm{C}_{\text {org }}$ in the soil. $\mathrm{C}$ concentration in the litter layer was not significant different across the chronosequence $(P=0.5)$. Schiffman et al. [21] also found no significant differences in the $C$ concentrations with stand age in the $\mathrm{O}_{\mathrm{L}}$ layer in a chronosequence of lobolly pine plantations, between 1 and 47 years old and established on previous agricultural land or cleared land.

However, afforestation caused a significant decrease in $\mathrm{C}$ concentration in the $\mathrm{O}_{\mathrm{H}}$ in the 40-yr stands at the end of the first rotation compared to $\mathrm{UN}$, while $\mathrm{C}$ concentration significantly increased again with stand age during the second rotation. The same pattern was observed in red pine plantations in Wisconsin [30] where, soil organic matter concentration (\%) increased linearly with stand age (13 to 48 years). However, [8] found no significant differences in the $\mathrm{C}$ concentration down to a soil depth of $10 \mathrm{~cm}$ in harvested stands of 5-yr, 15-yr, 40-yr old and old-growth Douglas fir stands in Canada. Smethurst et al. [23] 
observed that clearfelling decreased $\mathrm{C}$ concentration in the $0-15 \mathrm{~cm}$ depth from an initial value of $2.7 \%$ to $1.9 \%, 3$ years after replanting a Pinus radiata plantation, in South Australia.

$\mathrm{C}$ concentrations in the mineral layer were not significantly different across the chronosequence in Harwood; however, the $\mathrm{C}$ concentration in the mineral layer of the single $\mathrm{CF}$ site was slightly higher, compared with the corresponding one of the 40 -yr stands, indicating that mixing of the soil during/after clearfelling may result in some transfer of organic material deeper into the soil. Gholz et al. [7] also found no significant differences (or trend) in the organic matter concentrations in the mineral horizons of a slash pine chronosequence (stand ages between 2 and 34 years old) in Florida.

Afforestation on natural grassland, clearfelling and replanting also caused changes in the soil bulk densities, mainly in the organic layer. Bulk densities in the litter layer of all sites ranged between 0.1 and $0.2 \mathrm{~g} \mathrm{~cm}^{-3}$ and increased with increasing depth. Afforestation increased bulk density in the $\mathrm{O}_{\mathrm{H}}$ of the $40-\mathrm{yr}$ stand at the end of the first rotation $(P<0.001)$, which was accompanied by a decrease in total soil C. Soil bulk density is strongly inversely related to organic matter concentration [28] and decreases in organic matter result in increases in bulk density. The $\mathrm{O}_{\mathrm{L}}$ in the $40-\mathrm{yr}$ stand did not differ in bulk density from the $\mathrm{O}_{\mathrm{L}}$ of the ride, but appeared to have higher bulk density than the single CF, although the opposite would be expected. Bock and Van Rees [2] studied the effects of clearfelling on soil physical properties in white spruce forests in Canada. They found that, three years after harvesting, soil bulk densities in the LFH and the mineral layers were higher by 12 and $7 \%$, respectively compared with the bulk density in the respective layers of an uncut stand. This was due to the accelerated decomposition of organic matter. Johnson et al. [14] also found that clearfelling of hardwood and spruce forests in USA caused an increase of between 5 and $14 \%$ in bulk density in the top $20 \mathrm{~cm}$ of mineral soil. The increase depended on the severity of the disturbance. In our clearfelled site, the low bulk density was either a result of lack of replication or represented a small effect of the harvesting practices on soil compaction, or recovery since clearfelling (which had taken place 18 months before). Frazer et al. [6] also found similar bulk densities between clearfelled and uncut mixed conifer stands $\left(0.8\right.$ and $0.9 \mathrm{t} \mathrm{m}^{-3}$ respectively) in Sierra Nevada. They attributed it to cumulative action of frost and incorporation of residues into the soil, which was indicated by higher $\mathrm{C}$ concentration at the clearfelled site.

Soil bulk density in the organic layer decreased with stand age during second rotation reflecting increases in the soil $\mathrm{C}$. Switzer et al. [27] also found that soil bulk density decreased with stand age and organic matter concentration increased in oak-hickory-pine forest growing on abandoned agricultural land, in the South-eastern USA.

As mentioned before, bulk density increased with increasing depth, and the mineral layers had the highest bulk densities. These values were similar across stands indicating that the mineral layer was not directly affected by land use changes and stand growth. Bulk density also reflects the distribution of organic matter with depth as well as soil compaction [28]. Tamminen et al. [28] also found that soil bulk density increased with depth and remained uniform at depths of more than $20 \mathrm{~cm}$. Bock and Van Rees [2] found no significant differences in soil bulk densities of mineral layers between the clearfelled and uncut white spruce stands in Canada. Gholz et al. [7] also observed no significant differences in soil bulk densities in a slash pine chronosequence (stand ages between 2 and 34 years old) in Florida.

\section{CONCLUSIONS}

The establishment of Sitka spruce (Picea sitchensis) forests on previous grasslands on peaty gley soils have changed soil $\mathrm{C}_{\text {org }}$ content, concentration and bulk density. During the first rotation after afforestation $\mathrm{C}_{\text {org }}$ in the $\mathrm{O}_{\mathrm{H}}$ layer declined and the vertical distribution of the stocks changed, with more $\mathrm{C}_{\text {org }}$ stored in the $\mathrm{O}_{\mathrm{L}}$ and A layers. Clearfelling seemed to cause a further decline in $\mathrm{C}_{\mathrm{Org}}$ in the $\mathrm{O}_{\mathrm{L}}$ and $\mathrm{O}_{\mathrm{H}}$ but increased $\mathrm{C}_{\text {org }}$ in the A layer. Because of lack of replication, this finding will need to be confirmed. During second rotation, $\mathrm{C}_{\text {org }}$ progressively accumulated in $\mathrm{O}_{\mathrm{L}}$ and $\mathrm{O}_{\mathrm{H}}$. It is estimated that by the age of clearfelling of second rotation stands soil $\mathrm{C}_{\text {org }}$ stocks will have equalled those of the former unplanted grassland [31].

Acknowledgements: We wish to thank Henrike Gabler and Leonie FitzGerald who helped collecting and analysing the soil samples, and two anonymous referees for their helpful comments. Argyro Zerva was partly supported from the Greek State Scholarship Foundation (I.K.Y.). Additional resources were provided through EU CARBOAGE contract No EVK2-CT-1999-00045 and NERC grant No. GR9/ 4806.

\section{REFERENCES}

[1] Allen S., Chemical Analysis of Ecological Materials, 2nd ed., Blackwell Scientific Publications, Oxford, 1989.

[2] Bock M.D., Van Rees K.C.J., Forest harvesting impacts on soil properties and vegetation communities in the Northwest Territories, Can. J. For. Res. 32 (2002) 713-724.

[3] Cannell M.G.R., Dewar R.C., Pyatt D.G., Conifer plantations on drained peatlands in Britain: a net gain or loss of carbon? Forestry 66 (1993) 353-369.

[4] Dixon R.K., Brown S., Houghton R.A., Solomon A.M., Trexler M.C., Wisniewsk J., Carbon pools and fluxes of global forest ecosystems, Science 263 (1994) 185-190.

[5] FRA (Global Forest Resources Assessment), Food and Agriculture Organisation of the United Nations, 2000.

[6] Frazer D.W., McColl J.G., Powers R.F., Soil nitrogen mineralization in a clearcutting chronosequence in a northern California forest, Soil Sci. Soc. Am. J. 54 (1990) 1145-1152.

[7] Gholz H.L., Fisher R.F., Organic matter production and distribution in slash pine (Pinus elliottii) plantations, Ecology 63 (1982) 18271839.

[8] Griffiths R.P., Swanson A.K., Forest soil characteristics in a chronosequence of harvested Douglas-fir forests, Can. J. For. Res. 31 (2001) 1871-1879.

[9] Harmon M.E., Ferrell W.K., Franklin J.F., Effects on Carbon Storage of Conversion of Old-Growth Forests to Young Forests, Science 247 (1990) 699-702.

[10] Houghton R.A., Revised estimates of the annual net flux of carbon to the atmosphere from changes in land use and land management 1850-2000, Tellus B (55) (2003) 378-390.

[11] Howard P.J.A., The carbon-organic matter factor in various soil types, Oikos 15 (1965) 229-236. 
[12] IPPC, Land use, Land use change and Forestry, Special report of the Intergovernmental Panel on Climate Change, Watson R.T., Noble I.R., Bolin B., Ravindranath N.H., Verando D.J., Dokken D.J. (Eds.), Cambridge University Press, 2000.

[13] Johnson D.W., Curtis P.S., Effects of forest management on soil C and N storage: meta analysis, For. Ecol. Manage. 140 (2001) 227238.

[14] Johnson C.E., Driscoll C.T., Faley T.J., Siccama T.G., Hughes J.W., Carbon dynamics following clear-cutting of a northern hardwood forest, in: McFee W.W., Kelly M.J. (Eds.), Carbon Forms and Functions in Forest Soils, Soil Sci. Soc. Am., Madison Wisconsin, 1995, pp. 463-487.

[15] Keith H., Jacobsen K.L., Raison R.J., Effects of soil phosphorus availability, temperature and moisture on soil respiration in Eucalyptus pauciflora forest, Plant Soil 190 (1997) 127-141.

[16] King J.A., Smith K.A., Pyatt D.G., Water and oxygen regimes under conifer plantations and native vegetation on upland peaty gley soil and deep peat soils, J. Soil Sci. 37 (1986) 485-497.

[17] Konen M.E., Jacobs P.M., Burras C.L., Talaga B.J., Mason J.A., Equations for predicting soil organic carbon using loss-on-ignition for North Central USA soils, Soil Sci. Soc. Amer. J. 66 (2002) $1878-1881$.

[18] Post W.M., Emanuel W.R., Zinke P.J., Stangenberger A.G., Soil Carbon pools and world life zones, Nature 298 (1982) 156-159.

[19] Pyat D.G., Soil Classification, Forestry Commission research Information Note 68/62/SSN, Forestry Commission, Edinburgh, 1982.

[20] SAS Institute, SAS/STAT ${ }^{\text {TM }}$ User's Guide Release 6.03 Edition, SAS Institute, Cary, NC, USA, 1988.

[21] Schiffman P.M., Johnson W.C., Phytomass and detrital carbon storage during forest regrowth in the southeastern United States Piedmont, Can. J. For. Res. 19 (1989) 69-78.
[22] Schimel D., Terrestrial ecosystems and the carbon cycle, Glob. Change Biol. 1 (1995) 77-99.

[23] Smethurst P.J., Nambiar E.K.S., Changes in soil carbon and nitrogen during the establishment of a second crop of Pinus radiata, For. Ecol. Manage. 73 (1995) 145-155.

[24] Smith P., Powlson D.S., Glendining M., Smith J.U.O., Potential for carbon sequestration in European soils: preliminary estimates for five scenarios using results from long term experiments, Glob. Change Biol. 3 (1997) 67-69.

[25] Sollins P., Glassman C., Paul A.E., Swanston C., Lajtha K., Heil J.W., Elliott E.T., Soil Carbon and Nitrogen, Pools and Fractions, in: Robertson G.P., Coleman D.C., Bledsoe C.S., Sollins P. (Eds.), Standard Soil Methods for Long-Term Ecological Research, Oxford University Press, 1999, pp. 89-114.

[26] SPSS Inc., SPSS for Windows, Professional statistics, Release 9.0, 1998.

[27] Switzer G.L., Shelton M.G., Nelson L.E., Successional development of the forest floor and soil surface on upland sites of the East Gulf Coastal Plain, Ecology 60 (1979) 1162-1171.

[28] Tamminen P., Starr M., Bulk density of forested mineral soils, Silva Fenn. 28 (1994) 53-60.

[29] Thuille A., Buchmann N., Schulze E.-D., Carbon stocks and soil respiration rates during deforestation, grassland use and subsequent Norway spruce afforestation in the Southern Alps, Italy, Tree Physiol. 20 (2000) 849-857.

[30] Wilde S.A., Changes in soil productivity induced by pine plantations, Soil Sci. 97 (1964) 276-278.

[31] Zerva A., Ball T., Smith K.A., Mencuccini M., Soil carbon dynamics in a Sitka spruce (Picea sitchensis (Bong.) Carr.) chronosequence on a peaty gley, For. Ecol. Manage. 205 (2005) 227-240. 